Pacific Journal of Mathematics

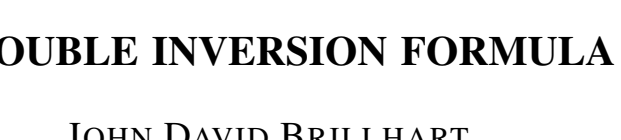




\section{A DOUBLE INVERSION FORMULA}

\section{JOHN BRILLHART}

Let $G$ be an abelian group and suppose $\left\{a_{n}\right\}$ and $\left\{b_{n}\right\}, n \geqq 1$, are sequences in $G$. Let $p$ be an odd prime and set $\eta_{e}=\left(e_{1} / p\right)$, the Legendre symbol, where $e=p^{s} e_{1}, s \geqq 0, p \nmid e_{1}$. Also, let $\chi_{e}^{ \pm}=\left(1 \pm \eta_{e}\right) / 2$. Define the sequence $\left\{c_{n}\right\}$ and $\left\{d_{n}\right\}, n \geqq 1$, by

$$
c_{n}=\sum_{e=n}\left(\chi_{e}^{+} a_{f}+\chi_{e}^{-} b_{f}\right)
$$

and

$$
d_{n}=\sum_{e f=n}\left(\chi_{e}^{-} a_{f}+\chi_{e}^{+} b_{f}\right)
$$

Theorem. For $n \geqq 1$ and $\mu$ the Möbius function,

$$
a_{n}=\sum_{e=n} \mu(e)\left(\chi_{e}^{+} c_{f}+\chi_{e}^{-} d_{f}\right)
$$

and

$$
b_{n}=\sum_{e f=n} \mu(e)\left(\chi_{e}^{-} c_{f}+\chi_{e}^{+} d_{f}\right) .
$$

Proof of the Theorem. Using (1) and (2) in (3) we obtain

$$
\begin{aligned}
\sum_{e f=n} \mu & (e)\left(\chi_{e}^{+} c_{f}+\chi_{e}^{-} d_{f}\right) \\
& =\sum_{e f=n} \mu(e) \sum_{r s=f}\left[\left(\chi_{e}^{+} \chi_{r}^{+}+\chi_{e}^{-} \chi_{r}^{-}\right) a_{s}+\left(\chi_{e}^{+} \chi_{r}^{-}+\chi_{e}^{-} \chi_{r}^{+}\right) b_{s}\right] \\
& =\sum_{e f=n} \mu(e) \sum_{s \mid f}\left(\chi_{n / s}^{+} \alpha_{s}+\chi_{n / s} b_{s}\right) \\
& =\sum_{s \mid n}\left(\chi_{n ; s}^{+} a_{s}+\chi_{n / s} b_{s}\right) \sum_{e|n| s} \mu(e)=a_{n} .
\end{aligned}
$$

Formula (4) is proven similarly.

Received June 8, 1979.

University of Arizona

Tucson, AZ 85721 



\section{PACIFIC JOURNAL OF MATHEMATICS}

\section{EDITORS}

DONALD BABBITT (Managing Editor)

University of Galifornia

Los Angeles, California 90024

Hugo RossI

University of Utah

Salt Lake City, UT 84112

C. C. MoOre AND ANDrew OGG

University of California

Berkeley, CA 94720

\section{J. DugundjI}

Department of Mathematics University of Southern California

Los Angeles, California 90007

R. Finn and J. Milgram

Stanford University

Stanford, California 94305

ASSOCIATE EDITORS

E. F. Beckenbachi

B. H. NeumanN

F. WOLF

K. YOSHIDA

\section{SUPPORTING INSTITUTIONS}

UNIVERSITY OF BRITISH COLUMBIA

CALIFORNIA INSTITUTE OF TECHNOLOGY

UNIVERSITY OF CALIFORNIA

MONTANA STATE UNIVERSITY

UNIVERSITY OF NEVADA, RENO

NEW MEXICO STATE UNIVERSITY

OREGON STATE UNIVERSITY

UNIVERSITY OF OREGON
UNIVERSITY OF SOUTHERN CALIFONIA

STANFORD UNIVERSITY

UNIVERSITY OF HAWAII

UNIVERSITY OF TOKYO

UNIVERSITY OF UTAH

WASHINGTON STATE UNIVERSITY

UNIVERSITY OF WASHINGTON

Printed in Japan by International Academic Printing Co., Ltd., Tokyo, Japan 


\section{Pacific Journal of Mathematics \\ Vol. 89 , No. 1 \\ May, 1980}

David Bressoud, A note on gap-frequency partitions ................ 1

John David Brillhart, A double inversion formula ................. 7

Frank Richard Deutsch, Günther Nürnberger and Ivan Singer, Weak

Chebyshev subspaces and alternation .......................

Edward Richard Fadell, The relationship between Ljusternik-Schnirelman

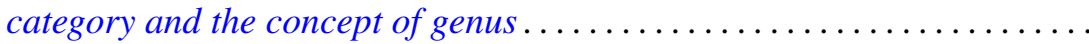

Harriet Jane Fell, On the zeros of convex combinations of polynomials.......

John Albert Fridy, An addendum to: "Tauberian theorems via block

dominated matrices" ..................................

Andrzej Granas, Ronald Bernard Guenther and John Walter Lee, Applications of topological transversality to differential equations. I. Some nonlinear

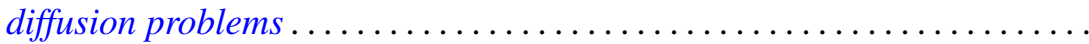

David E. Handelman and G. Renault, Actions of finite groups on self-injective

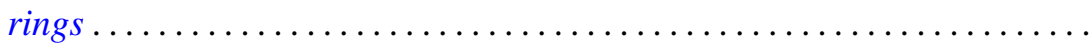

Michael Frank Hutchinson, Local $\Lambda$ sets for profinite groups .............

Arnold Samuel Kas, On the handlebody decomposition associated to a

Lefschetz fibration...

Hans Keller, On the lattice of all closed subspaces of a Hermitian space.....

P. S. Kenderov, Dense strong continuity of pointwise continuous

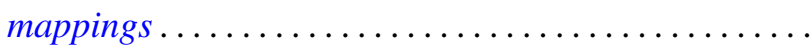

Robert Edward Kennedy, Krull rings.................

Jean Ann Larson, Richard Joseph Laver and George Frank McNulty,

Square-free and cube-free colorings of the ordinals ...

Viktor Losert and Harald Rindler, Cyclic vectors for $L^{p}(G)$

John Rowlay Martin and Edward D. Tymchatyn, Fixed point sets of

1-dimensional Peano continua...

Augusto Nobile, On equisingular families of isolated singularities ...

Kenneth Joseph Prevot, Imbedding smooth involutions in trivial bundles ...

Thomas Munro Price, Spanning surfaces for projective planes in four space.

Dave Riffelmacher, Sweedler's two-cocycles and Hochschild cohomology....

Niels Schwartz, Archimedean lattice-ordered fields that are algebraic over

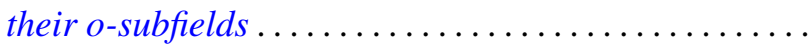

Chao-Liang Shen, A note on the automorphism groups of simple dimension groups.

Kenneth Barry Stolarsky, Mapping properties, growth, and uniqueness of

Vieta (infinite cosine) products ...

Warren James Wong, Maps on simple algebras preserving zero products. I.

The associative case ............................. 